\title{
EKSISTENSI GERAKAN WAHDAH ISLAMIYAH SEBAGAI GERAKAN PURITANISME ISLAM DI KOTA MAKASSAR
}

\author{
Marhaeni Saleh M \\ Dosen Aqidah dan Filsafat Islam \\ Fakultas Ushuluddin, Filsafat dan Politik \\ UIN Alauddin Makassar \\ E-mail: marhaeni.saleh.mallappa@gmail.com
}

\begin{abstract}
Abstrak
Tulisan ini membahas tentang eksistensi gerakan Wahdah Islamiyah sebagai gerakan puritanisme Islam di Kota Makassar. Adapun problem riset seputar; dinamika perkembangan Wahdah Islamiyah sebagai gerakan puritanisme Islam di kota Makassar, Implementasi ajaran Islam Wahdah Islamiyah di Kota Makassar. Penelitian ini termasuk kategori penelitian lapangan yang bersifat kualitatif-deskriptif, dengan menggunakan pendekatan filosofis, teologis, dan sosio-kultural, dengan metode analisis bersifat deskriptif-kritis. Wahdah Islamiyah adalah gerakan dakwah purifikasi atau pemurnian dan penyucian sifat Tauhid dan akidah umat Islam dari segala kemusyrikan. Gerakan tersebut berbentuk seruan kepada segenap lapisan masyarakat agar menjalankan kalimat syahadat yang telah mereka ikrarkan secara konsisten, Wahdah Islamiyah menjadikan akidah Ahlussunnah wal Jamaah sebagai manhaj dan dasar bagi pandangan dan gerakan purifikasinya. Meski Wahdah Islamiyah mengakui bahwa mereka adalah organisasi yang mengusung misi purifikasi Islam, bukan berarti Wahdah Islamiyah dapat dikategorikan sebagai kelompok takfiri. Wahdah Islamiyah adalah organisasi dan gerakan Islam yang memilih jalan wasathiyah (tengah/moderat) sebagai frame gerakannya. Wahdah Islamiyah bertransformasi menjadi gerakan yang lebih kontekstual dalam beradaptasi dengan kondisi dan kultur masyarakat. Gerakan dakwah dan tarbiyah menjadi model strategis bagi Wahdah Islamiyah dalam menjalankan misinya sebagai organisasi Islam yang puritan. Dakwah yang dilakukan tidak hanya bersifat formal namun juga fokus pada dakwah yang bersifat bil hal. Wahdah Islamiyah senantiasa mengedepankan cara-cara persuaif dan dialogis dalam mengembangkan metode dakwahnya di tengah masyarakat. Sebagai organisasi yang concern pada gerakan dakwah puritanisme Islam, Wahdah Islamiyah bertransformasi menjadi sebuah organisasi modern yang tidak hanya berkutat pada pendekatan dakwah yang bersifat klasikal saja. Wahdah Islamiyah melebarkan sayap gerakannya pada gerakan sosiokultural, ekonomi, politik, hingga gerakan keperempuanan. Pilihan pada model Islam wasathiyah membuat Wahdah Islamiyah kemudian hadir dalam wajah yang moderat, sehingga puritanisme Islam Wahdah Islamiyah terartikulasi dalam wajah yang khas Salafi Islahi, yaitu kelompok Islam yang sejatinya bercorak Salafi namun menghadirkan artikulasi yang moderat dan inklusif serta cenderung menempuh cara-cara modern dalam dakwahnya, Meski puritanis tapi Wahdah menampilkan wajah yang persuasif, meski sangat militan dalam prinsip namun Wahdah Islamiyah tetap tampil sebagai gerakan yang inklusif, meski revivalis tapi Wahdah Islamiyah tidak menggunakan cara
\end{abstract}


dan pendekatan politik dalam gerakannya melainkan menempuh cara-cara kultural. Oleh karena itu, paradigmatik Wahdah Islamiyah dapat dikategorikan sebagai kelompok puritan/pemurnian tetapi berwajah moderat Wahdah Islamiyah.

\section{Keywords:}

Eksistensi, Gerakan Islam, Wahdah Islamiyah, Puritanisme

\section{I.PENDAHULUAN}

Alquran dan hadis, keduanya merupakan pedoman bagi umat Islam. Alquran memerintahkan pada orang-orang yang beriman untuk mematuhi Allah SWT dan mengamalkan perintah-Nya yang tertera di dalamnya, serta mematuhi Rasul-Nya (alSunnah) karena dialah yang menjelaskan kandungan kitab tersebut kepada umat manusia, serta mematuhi Ulil Amri yang meliputi pemerintah, para hakim, para ulama, panglima perang, tokoh-tokoh terkemuka dan lainya, tempat di mana umat manusia mengambil rujukan dalam memenuhi kebutuhan hidupnya dan memecahkan berbagai masalah yang dihadapinya. ${ }^{1}$

Menurut Mustafa Al-Maragi, bahwa menaati Allah dan Rasul-Nya itu bersifat mutlak dan tanpa syarat. Sedangkan menaati ulil amri hanya ditujukan kepada mereka yang ahli amanah, tidak menyalahi perintah Allah dan Rasul-Nya yang diketahui secara mutawatir, serta pendapat-pendapatnya diakui dan disepakati oleh kebanyakan orang. ${ }^{2}$ Jadi menaati ulil amri bersifat relatif bukan absolut.

Cita-cita Islam pada hakekatnya merupakan cita-cita Alquran. Dalam kaitan ini Fazlur Rahman mengemukakan bahwa dasar ajaran Alquran ialah moral, yang memancarkan titik beratnya pada monoteisme dan keadilan sosial. Hukum moral tidak dapat diubah, ia merupakan "perintah" Tuhan; manusia tidak dapat membuat hukum moral: ia sendiri harus tunduk kepadanya, tunduk itu disebut "Islam" dan perwujudannya dalam kehidupan disebut "ibadah" atau pengabdian kepada Allah. Hal itu disebabkan bahwa tekanan Alquran terletak pada hukum moral, yakni Tuhan menurut Alquran dalam pandangan manusia pertama sekali ialah sebagai Tuhan Yang Maha Adil. Namun hukum moral dan nilai-nilai spiritual itu dapat diwujudkan, terlebih dahulu haruslah diketahui. ${ }^{3}$

Bersamaan dengan krisis, kegagalan dan ketertinggalan atas dunia Barat yang kian menguat, kesadaran atas pencarian kemurnian pun mencuat dan para intelektual muslim terlibat dalam perbincangan tentang ketertinggalan dunia Islam. Kegagalan yang nyaris sempurna dalam berbagai aspek kehidupan yang menimpa kaum muslim ini, di satu sisi melahirkan sikap curiga terhadap kultur Barat yang dianggap tidak cocok dengan kultur Islam oleh sebagian umatnya, dan di sisi lain juga mendorong

\footnotetext{
${ }^{1}$ Abuddin Nata, Peta Keragaman Pemikiran Islam di Indonesia (Cet. II; Jakarta: PT RajaGrafindo Persada, 2001), h. 1.

${ }^{2}$ Ahmad Mustafa Al-Maragi, Tafsir Al-Maragi, Jilid III (Beriut: Dar al-Fikr, [t.th]), h. 72

${ }^{3}$ Fazlur Rahman, Islam ( Chicago \& London: University of Chicago Press, 1979), Lihat Sonoaji Saleh Terj. Islam ( Jakarta: PT Bumi Aksara, 1992), h. 49.
} 
tumbuhnya sikap apologetik di kalangan umat Islam. Sikap anti Barat ditunjukkan dengan penolakan atas segala isu dan konsep yang berasal dari Barat. Dalam waktu bersamaan sikap apologetik ditunjukkan dengan pernyataan kembali kepada teks ajaran Islam yang telah sempurna mengatur segala aspek kehidupan.

Gerakan penolakan Barat atas nama kemurnian bukan berarti mempertahankan kemapanan. Gerakan pemurnian Islam tetap berpendirian bahwa perubahan merupakan sunnatullah, dunia harus berubah dari yang tidak baik menjadi baik, dari yang statis menjadi dinamis. Pencarian kemurnian mengandalkan inovasi dan kreativitas membangun formula yang tepat untuk lebih baik yang sesuai dengan prinsip-prinsip ajaran Islam. ${ }^{4}$

Di tengah gencarnya upaya pemurnian ajaran Islam, gerakan pembaruan Islam pun atau tajdid ${ }^{5} \mathrm{di}$ Indonesia telah menjadi bagian penting dalam sejarah umat Islam Indonesia. Awal abad XX menandakan sebuah perkembangan yang cukup menarik dalam proses terjadinya gerakan tajdid tersebut. Tajdid (bahasa arab) merupakan satu istilah yang dielaborasi untuk kata pembaruan yang berarti pembaruan pemikiran, aliran, gerakan, dan upaya mengubah paham-paham, adat-istiadat, dan kebiasan-kebiasaan lama yang melembaga untuk disesuaikan kembali dengan rujukan pokok ajaran Islam, yaitu Alquran dan Sunnah. ${ }^{6}$

Arus modernitas di dunia Islam juga sering dijadikan faktor penyebab bagi lahirnya gerakan-gerakan ekstrim. Modernitas menerjang dengan begitu cepat, dan sebagai sebuah kultur dominan, modernitas dengan nilai dan norma-norma baru telah meruntuhkan banyak sisi nilai atau tradisi lama, baik yang berasal dari spirit keagamaan ataupun budaya-budaya lokal. Terjangan modernitas juga meletupkan kekacauan, dalam suasana riuh-rendah modernitas yang membingungkan dan kacau-balau itulah maka dogmatisme keagamaan sering kali menjadi sarana pelarian. Secara ekstrem di bawah dogmatisme keagamaan ini pada akhirnya memunculkan kepatuhan mutlak bagi para anggotanya dan mereka siap melakukan apa saja demi nilai-nilai dogmatisme yang direngkuhnya itu. ${ }^{7}$

Perkembangan keagamaan di Indonesia dapat dipotret dengan memahami kaitan antara kecenderungan puritanisme-revivalisme Islam pada satu sisi dan moderasiinklusif pada sisi lain. Puritanisme-revivalisme menguat akibat langsung dari pengaruh paham keagamaan yang diimpor dari Timur Tengah, khususnya paham Wahabi yang menyerukan kembali kepada dasar-dasar agama sebagaimana dipraktekkan oleh kaum salaf dan memurnikan Islam dari bid'ah, peniruan buta (taklid), dan penyembahan

\footnotetext{
${ }^{4}$ Robert D Lee, Mencari Islam Autentik: Dari Nalar Puitis Iqbal Hingga Nalar Kritis Arkoun, Terj. Ahmad Baiquni (Bandung: Mizan, 2000), h. 14.

${ }^{5}$ Tajdid sering dikaitkan dengan hadis Rasulullah saw. Riwayat Abu Daud yang menyatakan: "Sesungguhnya Allah akan membangkitkan bagi umat ini pada permulaan setiap seratus tahun ada orang yang senantiasa memperbarui agama untuknya" (Lihat Rifyal Ka'bah, Hukum Islam di Indonesia (Jakarta: Universitas Yasri, 1999), h. 113.

${ }^{6}$ A. Latif Muchtar, Gerakan Kembali Ke Islam (Bandung: Rosda Karya, 1998), h. 215.

${ }^{7}$ M. Zaki Mubarak, Genealogi Islam Radikal di Indonesia: Gerakan, Pemikiran dan Prospek Demokrasi (Jakarta: Pustaka LP3ES Indonesia, 2007), h. 355.
} 
berhala (syirik). ${ }^{8}$ Sementara kecenderungan moderat-inklusif ditunjukkan dengan penerimaan terhadap konsep pemurnian agama dari Timur Tengah, tetapi tidak dilakukan secara rigid, melainkan disesuaikan dengan konteks sosio-kultural bangsa.

Kesadaran-kesadaran spiritual yang muncul melahirkan gerakan yang mempertahankan pemunian ajaran-ajaran agama yang dikenal dengan istilah "Puritanisme-Revivalis" oleh kelompok-kelompok keagamaan, di satu sisi dianggap dapat membangkitkan kembali semangat dalam kehidupan keagamaan, namun sekelompok orang menanggapi dengan sinis, curiga dan mengkhawatirkan eksistensi mereka terancam.

Dalam konteks semangat pembaruan, pemurnian, dan slogan kembali kepada Alquran dan hadis sebagaimana yang diuraikan di atas, Wahdah Islamiyah sebagai salah satu ormas Islam pada mulanya merupakan suatu gerakan Islam lokal yang menisbahkan dirinya kepada penyadaran, pencerahan, moral/akhlak, dan pendidikan, kini telah meluas ke berbagai wilayah di tanah air dengan jaringan organisasi yang cukup rapi dan kesadaran di kalangan aktivisnya mengenai pentingnya pembinaan dan pemberdayaan umat. ${ }^{9}$

Sebagai ormas Islam, Wahdah Islamiyah bukanlah organisasi yang tiba-tiba muncul, melainkan merupakan rangkaian dari berbagai peristiwa dan ketegangan teologis yang dialami oleh para pendiri organisasi ini dengan gerakan Islam Muhammadiyah di Makassar. ${ }^{10}$ Lahirnya ormas ini pada awalnya berembrio kuat dan mengakar kepada seorang tokoh bernama Fathul Muin. ${ }^{11}$ Semasa hidupnya, sosok Fathul Muin sangat intens dan banyak menghabiskan waktunya untuk memberikan pembinaan terutama kepada murid-murid yang dianggap militan dalam mendakwahkan Islam serta menjadi aktivis-aktivis gerakan Islam yang kuat. Sepeninggal Fathul Muin, para pengikutnya tetap aktif melakukan kegiatan-kegiatan tarbiyah. Goncangan pemikiran timbul pada tahun 1985 ketika kebijakan politik Orde Baru memberlakukan Pancasila sebagai satu-satunya azas kepada seluruh ormas Islam. Dalam konteks ini, sebagian pengikut fanatik Fathul Muin kecewa dengan penganut mayoritas ormas Muhammadiyah yang menerima pemberlakukan Pancasila sebagai satu-satunya azas. Spirit kaum muda Muslim yang menjadi aktivis Ikatan Pelajar Muhammadiyah (IPM) sangatlah kuat, mereka dibina langsung oleh Kiyai Fathul Muin dengan doktrin keagamaan puritan dan upaya tetap mempertahankan identitas keislaman bagi para

\footnotetext{
${ }^{8}$ Syarifuddin Jurdi, Wahdah Islamiyah dan Gerakan Transnasional: Hegemoni, Kompromi, dan Kontestasi Islam Indonesia (Yokyakarta: Laboratorium Sosiologi UIN Sunan Kalijaga, 2009), h. 2

${ }^{9}$ Syarifuddin Jurdi, Islam dan politik Lokal: Studi Kritis atas Nalar Politik Wahdah Islamiyah (Yokyakarta: Pustaka Cendekia Press, 2006), h. 147.

${ }^{10}$ Syarifuddin Jurdi, Islam dan .... h. 147.

${ }^{11}$ Fathul Muin Dg. Maggading adalah sosok ulama dan tokoh serta pengurus Muhammadiyah Wilayah Ujung Pandang (Sekarang disebut Makassar). Ia pernah memimpin DPW Muhammadiyah selama dua periode yakni tahun 1970-1980), Dg. Maggading menghabiskan waktunya membina jama'ah masjid Ta'mirul Masajid sehingga ia sangat dikagumi terutama di kalangan generasi muda dan mahasiswa Muhammadiyah dimana dari generasi muda inilah yang menjadi cikal bakal berdirinya Wahdah Islamiyah.
} 
kadernya dan jamaahnya di Masjid Ta'mirul Masajid Makassar milik Muhammadiyah Makassar. Berdirinya Wahdah Islamiyah pada esensinya sebenarnya merupakan manifestasi dari kegelisahan terhadap distorsi nilai-nilai agama dan prakteknya dalam masyarakat. Elit Wahdah Islamiyah menyadari bahwa kehadiran mereka memiliki alasan-alasan sosio-historis yang kuat, karena bertujuan untuk menciptakan struktur sosial politik baru masyarakat dari kecenderungan sekular untuk kembali kepada tradisi keislaman yang telah diwariskan oleh para pejuang Islam Makassar dan Sulsel sebelumnya.

Eksistensi gerakan Wahdah Islamiyah seperti halnya kebanyakan organisasi kemasyarakatan lainnya, tidak berjalan dengan mulus. Hal ini dibuktikan banyaknya prasangka-prasangka negatif yang berkembang menyoroti kehadiran organisasi ini. Terlebih lagi ketika melihat penampilan sebagian akhwat ${ }^{12}$ yang menggunakan cadar menutupi wajahnya. Persepsi negatif ekstrim yang muncul adalah kecurigaan dari berbagai pihak yang menginterpretasi Wahdah Islamiyah sebagai gerakan sempalan. Persepsi negatif interpretatif terhadap organisasi ini, oleh warga Wahdah Islamiyah di responi dengan sabar dan persuasif, sehingga seiring dengan usia organisasi, Wahdah Islamiyah mulai mendapat tempat dan dipandang sebagai organisasi kemasyarakatan yang kontemporer.

Klaim sebagai organisasi puritanis Islam, sedikit banyaknya telah membuat Wahdah Islamiyah diklaim sebagai bagian dari kelompok revivalisme Islam yang dianggap menyebarkan paham radikal dikalangan umat Islam. Terlepas dari klaim tersebut, Wahdah Islamiyah tetap eksis mengayuh semangat dakwah mereka melalui gerak organisasi yang tidak an sich berkutat dalam dakwah yang bersifat formal saja. Wahdah Islamiyah bertransformasi sebagai organisasi dakwah modern yang merengkuh aktivisme mereka di segala lini kehidupan umat. Aspek pendidikan, sosial, ekonomi, hingga kesehatan, menjadi concern mereka.

Kota Makassar menjadi tempat lahir, tumbuh, dan berkembangnya Wahdah Islamiyah, mulai dari masih berbentuk kelompok kajian, yayasan, hingga dideklarasikan sebagai organisasi masyarakat pada tahun 2002. Oleh karena itu, Makassar menjadi sebuah locus penelitian, regional, nasional, hingga global dari aktivitas Wahdah Islamiyah sebagai sebuah organisasi. Penelitian terhadap Wahdah Islamiyah di Kota Makassar berarti penelitian yang mencakup Wahdah secara universal, karena posisi Kota Makassar sebagai sentrum aktivitas organisasi Wahdah Islamiyah. Oleh karena itu, menarik untuk mengkaji konteks Wahdah Islamiyah sebagai organisasi puritanisme Islam dalam berbagai dinamika dan kiprah organisasi tersebut di Kota Makassar. Berdasarkan uraian latar belakang tersebut, masalah pokok dalam penelitian ini adalah bagaimana eksistensi gerakan Wahdah Islamiyah sebagai gerakan puritanisme Islam di Kota Makassar?

\footnotetext{
${ }^{12}$ Akhwat adalah sapaan yang digunakan bagi kaum perempuan dan ikhwan bagi kaum laki-laki, kedua sapaan ini berasal dari bahasa "arab" yang bermakna saudara, sapaan ini lumrah digunakan dikalangan Wahdah Islamiyah.
} 


\section{Eksistensi Gerakan Wahdah Islamiyah sebagai Gerakan Puritanisme Islam di Makassar}

Sebagai organisasi kemasyarakatan yang bergerak dibidang dakwah Islam, DPD Wahdah Islamiyah Kota Makassar memfokuskan program kerja pada tiga aspek kegiatan, yatu aspek dakwah, aspek sosial ekonomi, dan aspek pendidikan, hal ini sebagaimana penulis kutip dari laman resmi DPD Wahdah Islamiyah Kota Makasar. ${ }^{13}$ Dalam bidang program dakwah, DPD Wahdah Islamiyah Kota Makassar melaksanakan 5 kegiatan, yaitu penataran keislaman (daurah islamiyah), pembinaan keislaman secara kontinyu (tarbiyah islamiyah), ta'lim pekanan, pelayanan khutbah Jumat, serta pengelolaan website dakwah dan bulletin dakwah.

Penataran keislaman atau daurah islamiyah dilakukan di tingkat SLTA, perguruan tinggi dan masyarakat umum dengan tujuan untuk memberikan pengenalan dasar-dasar keislaman. Saat ini DPD Wahdah Islamiyah Kota Makassar banyak melakukan daurah islaiyah yang bekerjasama dengan ROHIS (Kerohanian Islam) di SLTA-SLTA di kota Makassar baik negeri maupun swasta. Serta di perguruan tinggi melalui kerjasama dengan Lembaga Dakwah Kampus (LDK), sedangkan untuk kalangan masyarakat umum, Wahdah Islamiyah biasanya bekerjasama dengan remaja masjid. Tarbiyah Islamiyah atau pembinaan keislaman secara kontinyu dilakukan sebagai follow up dari kegiatan daurah isamiyah yang diadakan dalam kelompok kecil (5-12 orang) yang dibimbing langsng oleh seorang murabbi/murabbiyah dengan kurikulum dan materi keislaman yang sistematis dan komprehensif. Ta'lim pekanan dilaksanakan di berbagai tempat, baik masjid, kampus, atau sekolah berupa pengajian umum, majelis taklim, maupun ta'lim Maghrib-Isya (dilakukan antara salat Maghrib dan isya).

Program di bidang sosial ekonomi meliputi 6 hal, yaitu; pelayanan penyelenggaraan jenazah, pelatihan penyelenggaraan jenazah, pelatihan dan pelayanan pengobatan ruqyah syar'iyah, penanggulangan musibah dan kebakaran, program anak asuh, serta khitanan massal dan donor darah. DPD Wahdah Islamiyah Kota Makassar melaksanakan pelayanan penyeleggaraan jenazah sesuai dengan tuntunan syariat Islam hingga ke pemakaman dan membebaskan biaya bagi masyarakat yang tidak mampu. Selain memberikan pelayanan langsung dalam hal penyelenggaraan jenazah, DPD Wahdah Islamiyah Kota Makassar juga pelatihan pengurusan jenazah baik yang secara langsung mereka laksanakan sebagai program maupun melayani permintaan pelatihan penyelenggaraan jenazah dengan tujuan untuk membimbing masyarakat agar dapat menyelenggarakan jenazah sesuai dengan tuntunan Alquran dan sunnah. Pelatihan pengobatan ruqyah syar'iyah dimaksudkan untuk memberikan petunjuk kepada masyarakat tentang metode pengobatan ruqyah syar'iyah (terapi kerasukan jin dan santet) agar masyarakat tidak terjatuh pada praktek perdukunan dan hal-hal lain yang

${ }^{13}$ Profil DPD Wahdah Islamiyah Kota Makassar dalam wahdah makassar.org. Diakses pada tanggal 15 Juni 2017. 
mengandung kesyirikan. Selain pelatihan, juga diberikan pelayanan langsung terkait pengobatan atau terapi atas kesurupan jin dan santet.

Selain itu, DPD Wahdah Islamiyah Kota Makassar juga memberikan pelayanan pengobatan Islami seperti bekam (hijannah). Penangguangan musibah dan kebakaran dilakukan melalui Tim Penanggulangan Musibah (TPM) khusus bagi warga Kota Makassar yang mengalami musibah kebakaran, banjir, angin puting beliung dan lainnya dengan mengumpulkan bantuan dan menyalurkannya kepada masyarakat yang terkena musibah. Program sosial lainnya adalah program anak asuh yaitu dengan memberikan bantuan pembiayaan pendidikan bagi anak kurang mampu yang memiliki prestasi yang baik di lingkungan sekolahnya. Program berikutnya adalah khitanan massal dan donor darah yang pelaksanaannya dilakukan setahun sekali dan pelaksanaannya digilir per kecamatan untuk membantu masyarakat yang tidak mampu mengkhitan anaknya.

Kerjasama eksternal dengan ormas atau lembaga lain diluar Wahdah Islamiyah juga aktif dilakukan baik melalui jalinan kerjasama program maupun dialog-dialog aktif, intensif, konstruktif, dan solutif dengan sesama ormas Islam yang lain dalam rangka membahas permasalahan-permasalahan keumatan yang bersifat aktual. Secara kelembagaan, Wahdah Islamiyah aktif di Majelis Ulama Indonesia (MUI) Kota Makassar dan memiliki perwakilan di lembaga tersebut. Dalam hal kegiatan kerjasama membangun suasana kerukunan umat beragama yang harmonis, Wahdah Islamiyah aktif di Forum Kerukunan Umat Beragama (FKUB). Hal-hal ini menunjukkan bahwa Wahdah Islamiyah bukanlah organisasi yang eksklusif, Wahdah Islamiyah menunjukkan keterbukaannya dalam hal taktis dan strategis guna member kontribusi bagi pembangunan masyarakat, khususnya di Kota Makassar.

Pilihan pada ideologi keagamaan yang bercorak pada model keislaman Salafisme di lapangan membuat Wahdah Islamiyah sering diasosasikan sebagai ormas Islam yang radikal. Harus diakui bahwa dalam beberapa hal berkenaan dengan pandangan dan praktek keagamaan, Wahdah Islamiyah yang bercorak Salafi memiliki perbedaan mendasar dengan pandangan dan praktek keagamaan kelompok Islam yang lain. Hadir dan berdakwah di tengah masyarakat yang masih kental dengan nuansa dan praktek tradisi membuat Wahdah Islamiyah kerap tertolak, meski harus diakui bahwa Wahdah Islamiyah telah cukup berhasil melakukan dakwah kislaman dengan manhaj Salafi ke masyarakat, khususnya di kalangan generasi muda di Makassar. Pilihan sebagai gerakan Salafi diakui oleh aktivis Wahdah Islamiyah, dengan menyebut bahwa Wahdah Islamiyah merupakan gerakan Salafi Modern. Pilihan sebagai gerakan salafi modern ini menimbulkan kritik dari sesama kelompok muslim yang bercorak Salafi lainnya.

Berbagai kritikan dan tantangan tersebut, merupakan dinamika bagi perjalanan dakwah dan organisasi Wahdah Islamiyah, sebagai ormas Islam yang bercorak Salafi, namun mengalami tantangan dan kritikan dari sesama kelompok Islam yang berhaluan salafi. Di sisi lain, pilihan sebagai organisasi dakwah yang berhaluan Salafi menjadi tantangan tersendiri bagi Wahdah Islamiyah ketika berhadapan dengan "arus besar" 
umat Islam di Makassar khususnya yang lebih dominan bercorak Islam tradisional. Tantangan dari dua sisi ini, senantiasa menjadi dinamika yang akan mewarnai perjalanan Wahdah Islamiyah sebagai organisasi kemasyarakatan Islam dengan identitasnya yang khas, khususnya di Kota Makassar.

\section{Wahdah dan Pandangan Puritanisme Islam}

Wahdah Islamiyah, sebagaimana diakui sendiri oleh Rahmat Abdul Rahman (Ketua Lembaga Kajian dan konsultasi Syariah Wahdah Islamiyah Makassar) adalah gerakan dakwah purifikasi atau pemurnian dan penyucian sifat Tauhid dan akidah umat Islam dari segala kemusyrikan. Gerakan tersebut berbentuk seruan kepada segenap lapisan masyarakat agar menjalankan kalimat syahadat yang telah mereka ikrarkan secara konsisten Wahdah Islamiyah menjadikan akidah Ahlussunnah wal Jamaah sebagai manhaj dan dasar bagi pandangan dan gerakan purifikasinya. Ahlussunnah wal Jamaah yang dimaksud dalam hal ini adalah pemahaman dan pengertian agama seperti yang dilakukan oleh Rasulullah saw dan ulama salafus saleh yang terdiri sahabat, tabi'in dan tabi'it tabi'in. . ${ }^{14}$ Pandangan ini ditegaskan sebagaimana dalam poin pertama misi organisasi Wahdah Islamiyah, yaitu sebagai lembaga dakwah yang mengembangkan syiar Islam dan menyebarkan pemahaman Islam yang sesuai dengan Alquran dan Sunnah berdasarkan pemahaman para Salafussalih.

Berkenaan dengan persoalan akidah Islam, Wahdah Islamiyah banyak merujuk pada kitab-kitab akidah/Tauhid dari ulama-ulama yang berhaluan pemikiran Salafi/Wahabi. Hal ini sebagaimana dituturkan oleh Ustadz Syaibani yang juga Sekjen DPP Wahdah Islamiyah. Kitab-kitab yang menjadi rujukan mereka dalam masalah akidah adalah kitab Ushul Tsalatsa dan Kitab Tauhid Karya Muhammad bin Abdul Wahab. ${ }^{15}$

Salafi/Wahabi merupakan gerakan puritan Islam yang paling menonjol dalam sejarah dan menjadi rujukan adalah gerakan-gerakan atau harakah-harakah Islam masa kini Pemikiran akidah kelompok Wahabi/Salafi berpedoman pada prinsip-prinsip dasar, yakni: (a) menghidupkan ilmu-ilmu keislaman (al-ilmu); (b) memurnikan tauhid dan memberantas kemusyrikan (al-tauhid); (c) menghidupkan sunnah dan memberantas bid'ah (al-sunnah); (d) pemurnian khazanah ilmu-ilmu keislaman (al-tasfiyah); (e) menyebarkan ajaran Islam yang lurus (al-dakwah); (f) menganjurkan kebaikan dan mencegah kemunkaran (amar ma'ruf nahi munkar); (g) menegakkan hukum Allah dalam pemerintahan dan masyarakat (tath biqus syari'ah); (h) membuka pintu-pintu ijtihad untuk menjawab masalah-masalah kontemporer umat (al-ijtihad); (i) membela agama Allah dan negeri-negeri Muslim dengan kekuatan senjata (jihad fi sabilillah); dan (j) mensucikan jiwa (at-tazkiyah). ${ }^{16}$

\footnotetext{
${ }^{14}$ Rahmat Abd. Rahman,"Wahdah Islamiyah Gerakan Purifikasi Akidah", www.wahdah.or.id. Diakses pada tanggal 7 Juni 2017. di Makassar

${ }^{15}$ Wawancara dengan Ustadz Syaibani Sekjen DPP Wahdah Islamiyah tanggal 10 Januari 2018

${ }^{16}$ Lihat AM. Waskito, Bersikap Adil Kepada Wahabi: Bantahan Kritis dan Fundamental Terhadap Buku Propaganda Karya Syaikh Idahram, (Jakarta: Pustaka alKautsar, 2012), hal. 206-222.
} 
Wahdah Islamiyah menekankan postulat pemikiran purifikasinya pada pemurnian akidah dari unsur-unsur kesyirikan. Tauhid adalah tujuan diciptakannya alam semesta. Para Rasul diutus untuk mendakwahkannya. Demikian pula Al Qur'an memberikan perhatian yang sangat besar dalam masalah tauhid, di sebagian besar suratsurat yang terdapat di dalamnya. Allah Ta'ala telah menerangkan bahaya lawannya yaitu syirik bagi pribadi dan masyarakat. Karena syirik merupakan sebab kehancuran di dunia dan kekal di dalam neraka. Sifat Tauhid dan akidah Islam yang bersih membuat visi hidup setiap manusia menjadi lurus, kehidupan akan dilalui dengan kegiatan yang memberi manfaat bagi diri sendiri dan orang lain. Visi kehidupan yang lurus berarti pemahaman terhadap maksud dan tujuan hidup di alam dunia, serta menyiapkan perbekalan buat sampai kepada kehidupan akhirat. Sifat tauhid menjadi sumbu dalam kehidupan seorang manusia dan masyarakat, segala aktivitas yang dihasilkan oleh sifat ini akan berbuah baik dan membuat arus pusaran kebaikan pada lingkungan yang ada di sekelilingnya. Perumpamaan kalimat tauhid di dalam Alquran, adalah ibarat pohon tinggi menjulang ke langit dan berakar tunjang menghunjam ke dalam perut bumi, buahnya dapat dinikmati setiap saat oleh siapapun yang melewatinya (QS. Ibrahim/14: 24-25), atau ibarat pelita yang menerangi kegelapan (QS. al-An'am/6: 122). ${ }^{17}$

Pemurnian Tauhid dan akidah Islam menjadi seruan prioritas dalam dakwah Wahdah Islamiyah. Pemurnian Tauhid merupakan ruh yang selalu ditiupkan ke dalam jiwa setiap kader dan aktivis Wahdah Islamiyah. Berpedoman kepada Rasulullah saw. yang memulai gerakan dakwah dengan penyadaran terhadap Kemahaesaan Allah swt. untuk disembah, segenap permasalahan pada masa Jahiliyah dihubungkan dengan kerusakan visi Ketuhanan mereka yang berwujud pada kemusyrikan, sehingga perbaika $\mathrm{n}$ sistem bermasyarakat dimulai dari titik sentral tauhid dan akidah. ${ }^{18}$ Puritanisme atau tasfiyah. Wahdah islamiyah prinsipnya Alquran dan Sunnah sebagaimana puritanisme dalam pandangan Ahlussunnah wal Jamaah, dalam artian menjaga kemurnian agama, Wahdah Islamiyah bergerak di situ, dalam prinsip atau tsawabit, hal-hal yang sifatnya mahdah atau sifatnya tetap, Dewan Syariah (DPP). Wahdah Islamiyah berusaha menjaga ke murnian ajaran Islam dalam hal penyucian akidah umat. ${ }^{19}$

Menurut Iskandar Kato (Kepala Biro Aset DPP Wahdah Islamiyah), pemikiran purifikasi Islam Wahdah Islamiyah adalah pemurnian pada seluruh lini kehidupan dari hal-hal yang menyimpang dari prinsip ajaran Islam sebagaimana yang termaktub dalam Alquran dan Sunnah. Manhaj pemurnian Islam adalah berpegang pada tekstualitas Alquran dan Sunnah pada perkara-perkara yang dianggap qath'i. ${ }^{20}$ Menurut Ustaz Syaibani, pemurnian Islam yang dilakukan oleh Wahdah Islamiyah terutama pada masalah Akidah dan ibadah yang bersifat mahdah (langsung). Akidah dan ibadah-

\footnotetext{
${ }^{17}$ Rahmat Abd. Rahman,"Wahdah Islamiyah.... “

${ }^{18}$ Rahmat Abd. Rahman,"Wahdah Islamiyah.... “" Makassar

${ }^{19}$ Wawancara dengan Ustaz Syaibani Sekjen DPP Wahdah Islamiyah tanggal 10 Januari 2018 di

${ }^{20}$ Wawancara dengan Ustaz Iskandar Kato Kepala Biro Asset DPP Wahdah Islamiyah tanggal 12 Desember 2017.
} 
ibadah yang mahdah tidak boleh ditambah, termasuk metode talaqqi atau berislam harus didasarkan pada ketentuan nas Alquran dan Sunnah. Nas didahulukan dari akal atau sami'na waata'na, akal digunakan untuk menimbang dan mencerna makna dari nas-nas yang ada, bukan "mengutak-atiknya" sebagaimana yang dilakukan oleh kelompok liberal. Jika akal tak mampu memaham maksud dari nas, khususnya pada ayat-ayat mutasyabihat makaakal harus tunduk pada makna lahir(tekstual) dari nas, tanpa boleh "mengakal-akalinya". ${ }^{21}$

Pemaparan di atas menunjukkan model epistemologi puritanisme pemikiran Wahdah Isamiyah yang mengutamakan penggunaan nalar bayani dalam memahami dan mencerna nas Alquran dan Sunnah. Epistemologi bayani berpijak pada teks, dan yang dimaksud di sini adalah Alquran dan hadis atau riwayat keagamaan lainnya. Karena itu, epistemologi bayani menaruh perhatian besar dan sangat teliti pada proses transmisi teks dari generasi ke generasi. Hal ini menjadi sangat urgen, karena benar tidaknya transmisi teks sangat menentukan benar tidaknya pengetahuan yang didapatkan. Jika proses transmisi teks bisa dipertanggungjawabkan, maka teks tersebut benar dan bisa dijadikan sumber kebenaran. Dan sebaliknya jika proses transmisi teks tidak bisa dipertanggungjawabkan, maka dengan sendirinya kebenaran dari teks tersebut pun diragukan. Karena epistemologi bayani sangat menekankan otoritas teks sebagai sumber kebenaran, namun pada praksisnya ada yang memahami teks secara langsung sebagai sumber pengetahuan jadi dan langsung mengaplikasikan tanpa perlu pemikiran. Secara tidak langsung berarti memahami teks sebagai pengetahuan mentah hingga perlu penafsiran dan penalaran. Meski menggunakan penalaran dan penafsiran dalam memahami teks, posisi teks sebagai otoritas kebenaran tetaplah tidak terganti, dalam artian rasio tidak bebas menentukan makna dan maksud dari teks, tetapi tetap harus bersandar pada teks, rasio dianggap tidak mampu memberikan pengetahuan kecuali ddisandarkan pada teks. ${ }^{22}$ Tekstualitas epistemology Wahdah Islamiyah tampak pada pandangan mereka yang lebih cenderung mengutamakan pemaknaan lahiriyah teks dibandingkan penggunaan rasio. Dari tekstualitas pemahaman keagamaan inilah, Wahdah Islamiyah menyusun pandangan purifikasi mereka tentang keislaman.

Pandangan puritanisme Wahdah Islamiyah, selain pada aspek akidah, mereka juga menekankan purifikasi pada ranah ibadah dan syariat. Hal inilah yang membuat Wahdah Islamiyah selain sering menggunakan jargon syirik, juga kerap melontarkan jargon bid'ah untuk setiap perkara keagamaan yang tidak memiliki dasar dalam Alquran dan hadis. Sebagaimana kelompok puritan Islam lainnya,Wahdah Islamiyah menjadikan tema bid'ah sebagai salah satu tema sentral dalam dakwah mereka. Dalam pandangan kaum puritan, segala praktek keagamaan yang tidak memiliki landasan dalil dari

\footnotetext{
Makassar

${ }^{22}$ Selain nalar bayani dalam pemikiran Islam juga dikenal dua pendekatan lainnya,yaitu nalar burhani yang menekankan penggunaan rasio (aql) dan nalar irfani yang menekankan pendekatan intuisi(dzawq). Lihat Khudori Saleh. Wacana Baru Filsafat Islam,(Yogyakarta: Pustaka Pelajar,2002), h.120-145.
}

${ }^{21}$ Wawancara dengan Ustaz Syaibani Sekjen DPP Wahdah Islamiyah tanggal 10 Januari 2018 di 
Alquran maupun Sunnah adalah bid'ah, dan bid'ah adalah perkara yang menyimpang dari Islam. Menurut Ustaz Syaibani bid'ah adalah sesuatu yang disandarkan pada agama yang tidak ada contoh sebelumnya, wahdah sangat berhati-hati dalam menimbang setiap perkara keagamaan yang dipraktekkan. ${ }^{23}$

Secara umum kaum puritanis adalah kelompok yang cenderung anti pada percampuran Islam dan tradisi lokal. Sebagaimana dikatakan oleh Khaled Abou Fadel kaum puritanis Islam cenderung puris dalam artian tidak toleran terhadap berbagai sudut pandang dan berkeyakinan bahwa realitas pluralistik merupakan kontaminasi terhadap autentitas. ${ }^{24}$ Menurut kaum puritan, setiap Muslim wajib kembali kepada Islam yang lurus dan sederhana, hal itu bisa diperoleh hanya dengan kembali kepada penerapan literal terhadap perintah-perintah dan Sunnah Nabi, serta pelaksanaan yang ketat terhadap praktek-praktek ritual. Orientasi puritan juga menganggap bentuk pemikiran moral yang tidak sepenuhnya bergantung pada teks sebagai bentuk dan menganggap pengetahuan humanistic, seperti teori sosial, filsafat, atau pemikiran spekulatif lainnya, sebagai "ilmu setan". ${ }^{25}$ Pandangan tersebut meski dengan sedikit lebih "moderat" adalah juga diyakini oleh Wahdah Islamiyah sebagai dasar pandangan puritanisme Islamnya.

Secara umum WI menganjurkan jamaahnya untuk berperilaku secara konservatif, dan berusaha mencontoh perilaku Rasulullah sebagai rujukannya misalkan kewajiban sholat berjamaah di masjid. Demikian juga bagi jamaah wanita diperintahkan mengenakan pakaian yang menutup rapat aurat, sehingga banyak jamaahnya yang menggunakan cadar. Selain itu jamaah menolak untuk bersalaman antara laki-laki dan perempuan yang bukan muhrimnya, dan dalam pesta perkawinan mereka menolak tradisi dalam pesta mempelai duduk berdua. Dimana tradisi budaya yang selama ini banyak mengintervensi aqidah terlalu jauh harus dihindari dimana prinsip dasar agama yang berhubungan ibadah harus dipisahkan dari ketentuan tradisi lokal, prinsip ini lazim di kalangan Muhammadiyah, dimana semua rujukan hanya pada Alquran dan Sunnah Rasulullah. ${ }^{26}$

Sikap apriori terhadap praktek tradisi keislaman dengan klaim bid'ah tampak dalam pernyataan Ustaz Iskandar Kato mengenai bid'ahnya beberapa tradisi yang dipraktekkan oleh masyarakat muslim Bid'ah adalah hal yang baru dalam konsep ibadah, termasuk diantaranya adalah perayaan-perayaan tertentu yang tidak ada dasarnya adalah bid'ah contoh peringatan maulid Nabi dan peringatan isra'mi'raj. ${ }^{27}$ Pandangan ini menunjukkan paradigma dan sikap Wahdah Islamiyah yang cenderung

\footnotetext{
${ }^{23}$ Wawancara dengan Ustaz Syaibani Sekjen DPP Wahdah Islamiyah tanggal 10 Januari 2018 di Makassar

${ }^{24}$ Khaled Abou El Fadl, Selamatkan Islam dari Muslim Puritan, terj. Helmi Mustofa (Jakarta: Serambi, 2005), h. 118.

${ }^{25}$ Khaled Abou El Fadl, Selamatkan Islam... h. 121.

${ }^{26}$ Nuhrison M.Nuh, Zainal Abidin, dan Sri Sulastri, "Wahdah Islamiyah di Makassar" ....h. 216.

${ }^{27}$ Wawancara dengan Ustaz Iskandar Kato Kepala Biro Asset DPP Wahdah Islamiyah tanggal 12Desember 2017.
} 
ekstrem dalam menyikapi tradisi masyarakat Islam. Praktek tradisi keagamaan masyarakat tersebut korupsi keagamaan (bid'ah) telah melanda umat sehingga agama yang mereka anut bukan merupakan Islam yang benar dan murni. ${ }^{28}$

Bagi Wahdah Islamiyah dalam melihat Islam secara kaffah (totalitas), yatu secara teks dan konteks agar hidup ini bermakna terutama dalam kehidupan sosial. Jika demikian, maka tak akan ada lagi istilah khilafiyah, dan bid'ah dalam kehidupan umat Islam akan sirna. Pengkultusan pendapat dan perselisihan akan hilang, tak akan ada lagi istilah ahli bid'ah, karena kaum muslimin akan mampu membedakan sesuatu secara normatif dan substansial. ${ }^{29}$

Wahdah Islamiyah, meski terkategorisasi sebagai kelompok Islam dengan pemikiran keagamaan yang puritan, bukan berarti puritanisme membuat Wahdah Islamiyah terjebak pada pemahaman ortodoksi keagamaan yang sangat kaku. Wahdah Islamiyah sangat terbuka untuk melakukan diskusi dan bersikap terbuka dalam beberapa poin pemikiran keislaman, khususnya dalam konteks muamalah atau membahas masalah-masalah keumatan yang kontemporer. Wahdah Islamiyah lebih menggunakan pendekatan persuasif dan dialogis dalam menyampaikan pandangan-pandangannya juga dalam menghadapi kelompok-kelompok yang kontra terhadap mereka. ${ }^{30}$

Pilihan terhadap konsep Islam wasathiyah (pertengahan) menunjukkan sisi moderasi pemikiran Wahdah Islamiyah dibandingkan pemikiran keagamaan kelompok Salafi lainnya. Bagi Wahdah Islamiyah, Islam wasathiyah adalah sikap yang pertengahan dalam menyikapi segala hal. Menyikapi kelompok radikalisme Islam, seperti ISIS misalnya, Wahdah Isamiyah menentang setiap bentuk praktek radikalisme Islam seperti yang ditunjukkan oleh ISIS. Ketika marak isu tentang ISIS, Wahdah Islamiyah membuat tabligh akbar yang berisi mengenai penentangan mereka terhadap ISIS, bahwa gerakan ISIS tidak sesuai dengan manhaj dan metode gerakan Wahdah Islamiyah. $^{31}$

Meski Wahdah Islamiyah mengakui bahwa mereka adalah organisasi yang mengusung misi purifikasi Islam, bukan berarti Wahdah Islamiyah dapat dikategorikan sebagai kelompok takfirisme. Dalam pandangan Wahdah Islamiyah, organisasi hanyalah kendaraan, Wahdah memandang orang muslim di luar mereka sebagai sesama saudara muslim. ${ }^{32}$ Hal inilah yang menunjukkan bahwa Wahdah Islamiyah adalah organisasi puritanis yang cukup moderat. Paradigma Islam puritan sebagaimana yang disebut oleh Khaled Abou fadl, bahwa Islam itu sudah sempurna, kesempurnaan itu

\footnotetext{
${ }^{28}$ Khaled Abou El Fadl, Selamatkan Islam... h. 132

${ }^{29}$ Sirajuddin Ismail, :"Wahdah Islamiyah di Kota Makassar" dalam Abdul Kadir Ahmad (ed), Varian Gerakan Keagamaan, (Makassar: Balai Penelitian dan Pengembangan Agama Makassar, 2007), h. 145 . Makassar

${ }^{30}$ Wawancara dengan Ustaz Syaibani Sekjen DPP Wahdah Islamiyah tanggal 10 Januari 2018 di

${ }^{31}$ Wawancara dengan Ustaz Syaibani Sekjen DPP Wahdah Islamiyah tanggal 10 Januari 2018 di Makassar

${ }^{32}$ Wawancara dengan Ustaz Syaibani Sekjen DPP Wahdah Islamiyah tanggal 10 Januari 2018 di Makassar
} 
berarti bahwa Islam itu tidak merekonsiliasikan dirinya atau membuktikan dirinya sesuai dengan sistem pemikiran lainnya. Islam merupakan sebuah sistem keyakinan dan hukum yang sudah lengkap dalam dirinya yang mencoba membentuk dunia dalam gambarannya, ketimbang mengakomodasi pengalaman manusia. ${ }^{33}$ Secara umum cukup tepat untuk membedah pemikiran puritanisme Islam ala Wahdah Islamiyah, meski secara khusus Wahdah Islmiyah secara pemikiran lebih sedikit infklusif dibandingkan kelompok pruitanis Islam lainnya. Perlu digaris bawahi bahwa Wahdah Islamiyah bersikap inklusif dan terbuka kepada sesama kelompok Sunni lainnya, namun terhadap kelompok diluar Sunni, semisal Syiah dan Ahmadiyah, bagi Wahdah kelompok tersebut telah melakukan penyimpangan terhadap Islam yang bersumber dari Alquran dan Sunnah

Sikap "moderat" Wahdah Islamiyah inilah yang membuat mereka di mata kelompok Salafi lainnya sebagai kelompok yang "kurang salafi". Wahdah Islamiyah mendapatkan kritik tajam bahkan hingga "penyesatan" dari kelompok Salafi lainnya, khususnya dari kelompok Salafi Manhaj as-Sunnah". ${ }^{44}$ Wahdah Islamiyah sendiri, menanggapi kritikan tersebut dengan sikap yang persuasif tanpa pernah terpancing untuk membalasnya. Pilihan pandangan dan metode Wahdah Islamiyah yang dianggap "kurang salafi"oleh kelompok Salafi lainnya menunjukkan transformasi pandangan puritanisme Wahdah Islamiyah yang mengarah pada haluan "tengah-kanan". Wahdah Islamiyah memberikan corak atau warna baru dalam pandangan puritanisme Islam yang berbeda dengan kelompok Islam puritan lainnya.

\section{Wahdah Islamiyah sebagai Gerakan Puritanisme Islam}

Ketika organisasi Wahdah Islamiyah didirikan pada tahun 2002, dengan tegas dinyatakan bahwa organisasi ini adalah organisasi dakwah dan tarbiyah yang bersumber pada Alquran dan Sunnah sesuai dengan pemahaman al-Salaf al-Salih (manhaj) Ahlussunnah wal Jamaah (Pasal 2 Anggaran Dasar Wahdah Islamiyah). Tujuan dari gerakan Wahdah Islamiyah tampak dalam pasal 3 Anggaran Dasar.'Mewujudkan dan membina masyarakat yang beriman dan bertakwa kepada Allah Azza wa Jalla berdasarkan Alquran dan Sunnah sesuai dengan pemahaman al-Salaf al-Salih (manhaj) Ahlussunnah wal Jamaah dan menegakkan Tauhid dan menghidupkan Sunnah serta memupuk ukhuwah Islamiyah untuk terwujudnya kehidupan bermasyarakat, berbangsa, dan bernegara yang diridhai Allah Azza wa Jalla."dengan demikian, membaca gerakan Wahdah kita akan menemukan beberapa kata kunci, yaitu; Gerakan dakwah dan tarbiyah, menegakkan tauhid, menghidupkan sunnah, dan memupuk ukhuwah, dasar

\footnotetext{
${ }^{33}$ Khalid Abou El Fdl, "The Human Righs Commitment in Modern Islam" dalam Josef Runzo dan Nancy M. Martin (ed). Human Righs and Responsibilities in the World Religion (Oxford: Oneworl, 2003), h. 309.

${ }^{34}$ Kelompok ini di Makassar berpusat di Jalan Baji Rupa,Makassardan dipimpin oleh Ustaz Zulkarnain. Kelompok ini merupakan gerakan Salafi ortodoks yang kerap menggelar ceramah umum atau opini tentang "kesesatan" Wahdah Islamiyah. Pada awalnya Ustaz Zulkarnain dan kelompok Salafi dengan para pendiri Wahdah berada dalam satu abrisan dakwah di Makassar, namun pada pertengahan tahun 1990-an keduanya berpecah karena beberapa pandangan dan metode yang berbeda dan tidak bisa dipertemukan.
} 
pandangan Wahdah adalah Ahlussunnah wal Jamaah dengan manhaj salafussalih. Berdaarkan kata kunci yang diambil dari anggaran dasar organisasi Wahdah Islamiyah tersebut, tampak jelas bahwa Wahdah Islamiyah sebagai gerakan Islam puritan dan hal ini pun diakui oleh tokoh-tokoh Wahdah Islamiyah.

Menurut Rahmat Abdul Rahman, Wahdah Islamiyah adalah gerakan keagamaan yang berorientasi pada pemahaman dan pengamalan beragama seperti yang dilakukan oleh Rasulullah saw. dan ulama salaf salih, yaitu para sahabat, tabiin dan tabi' tabiin, menjadi pondasi buat melakukan gerakan perbaikan umat. Wahdah Islamiyah menyadari dengan baik, bahwa Rasulullah saw. dan ulama salaf saleh telah mewariskan kekayaan (sarwah) ilmiah dan amaliah yang tidak pernah usang dimakan zaman, nasnas Alquran dan hadis diimplementasikan dalam pemahaman dan pengamalan yang sempurna. Menurut Imam Malik bin Anas, umat Islam zaman sekarang akan menjadi baik, apabila konsisten dengan ajaran yang menjadikan umat Islam zaman dahulu juga baik. Konsep Ahlussunnah Waljamaah yang dikembangkan oleh Wahdah Islamiyah bersifat konsisten dan dinamis. Konsisten dalam menjadikan pemahaman ulama salaf saleh yang berdasarkan atas nas-nas Alquran dan hadis sebagai acuan gerakan perbaikan umat, dan dinamis dalam realisasi pengamalan beragama dan berdakwah sesuai kaidahkaidah yang bersumber dari Alquran dan hadis pula. ${ }^{35}$ Wahdah Islamiyah senantiasa berusaha menuntun umat untuk bersikap kritis dalam masalah keislaman sehingga bisa membedakan mana akidah (ushuliyyah) dan kultur (furuiyyah) dan berjuang dengan semangat iqra' secara teks dan konteks ajaran Islam. ${ }^{36}$

Perkembangan zaman di bidang informasi, teknologi dan bidang-bidang lainnya menuntut agar kaidah-kaidah agama diterapkan dengan pemahaman dan metodologi yang benar dan bijak. Nilai-nilai kemuliaan yang ada pada zaman Rasulullah saw. berupaya diwujudkan kembali oleh gerakan Wahdah Islamiyah secara bersih dengan menjaga keseimbangan zaman dan lingkungan keberadaannya. Perilaku umat Islam pada zaman itu berupaya ditransformasikan pada kondisi kekinian dengan mengacu pada prinsip utama beragama, yaitu ajaran tauhid atau kemurnian ibadah kepada Allah swt. $^{37}$

Sebagai sebuah gerakan puritanisme Islam, ideologi Wahdah Islamiyah sangat dipengaruhi oleh ideologi gerakan revivalisme Islam sebagaimana tampak pengaruh tersebut pada kelompok Islam puritan lainnya di Indonesia. Menurut Syarifuddin Jurdi, pengaruh ideologi gerakan revivalis Islam terhadap pertumbuhan dan perkembangan gerakan Islam diIndonesia adalah; Pertama, Islam adalah pandangan hidup yang total dan lengkap. Kedua, kegagalan masyarakat muslim disebabkan penyimpangan mereka dari jalan lurus Islam dengan mengikuti jalan sekuler Barat. Ketiga, Pembaruan masyarakat mensyaratkan kembali kepada Islam. Keempat, Untuk memudahkan dan meresmikan kekuatan total tatanan sosial Islam yang sejati, hukum-hukum yang

\footnotetext{
${ }^{35}$ Rahmat Abd. Rahman,’Wahdah Islamiyah.... “

${ }^{36}$ Sirajuddin Ismail, :"Wahdah Islamiyah di Kota Makassar"... h. 128.

${ }^{37}$ Rahmat Abd. Rahman,"Wahdah Islamiyah.... “"
} 
terinspirasi dari Barat harus digantikan dengan hukum Islam yang merupakan satusatunya cetak biru yang bisa diterima bagi masyarakat muslim. Kelima, meski westernisasi dikecam tapi modernisasi tidak, ilmu pengetahuan dan teknologi diterima tapi keduanya harus ditundukkan dibawah akidah dan nilai-nilai Islam. Keenam, proses Islamisasi atau lebih tepatnya re-Isamisasi memerlukan organisasi-organisasi atau serikat-serikat yang berdedikasi dan terlatih ${ }^{38}$

Kendati menerima sejumlah gagasan revivalis Islam yang berkembang di Timur Tengah, tetapi tidak semua gagasan tersebut diadopsi oleh Wahdah Islamiyah. Pemikiran dan ideologi gerakan revivalis dikontekstualisasikan oleh Wahdah islamiyah sesuai dengan lokus dakwah mereka di Indonesia. Dengan demikian, Wahdah Islamiyah tidak sepenuhnya persis dengan gerakan revivalis lainnya. Guna memahami hal tersebut, Syarifuddin Jurdi membagi perjalanan gerakan Wahdah Islamiyah menjadi 3 fase krusial; Pertama,fase pembentukan gerakan sekaligus fase adopsi gerakan yang diimpor dari Timur-Tengah. Fase ini berlangsung antara tahun 1988-1994, khususnya pada pembentukan identitas gerakan. Pada periode ini gerakan tarbiyah Ikhwanul Muslimin banyak menginspirasi para aktivis yang nantinya mejadi pendiri Wahdah Islamiyah. Kedua, fase penguatan identitas keindonesiaan Wahdah Islamiyah, periode ini antara tahun 1994-1998. Nilai-nilai yang diperjuangkan Wahdah Islamiyah pada masa itu, nilai-nilai Islam yang bersumber pada Alquran dan Sunnah yang shahih, tetapi disesuaikan dengan konteks keindonesiaan dan konteks kultur masyarakat Makassar dan Sulawesi Selatan. Pengaruh ideoloi trans-nasional yang menjadi acuan pada periode awal berdirinya segera dimodifikasi dan disederhanakan agar sesuai dengan nilai-nilai lokal dan budaya bangsa Indonesia. Ketiga, periode penguatan identitas dan transformasi gerakan dari yayasan menjadi ormas Wahdah Islamiyah antara 1998-2002. Periode ini merupakan periode pergulatan gerakan dengan situasi politik bangsa yang sedang mengalami perubahan, tidak hanya berkaitan dengan pergantian kepempimpinan bangsa tetapi juga peluang-peluang politik yang tersedia dimungkinkan proses transformasi dan pembentukan ulang identitas gerakan. Keempat, sejak 2002 Wahdah Islamiyah secara resmi menjadi ormas Islam Indonesia yang tidak lagi memfokuskan perhatiannya pada Makassar dan Sulawesi Selatan, tetapi melakukan transmisi gerakan ke seluruh Indonesia, agenda Wahdah Islamiyah yang paling menonjol adalah penguatan basis-basis gerakan di sejumlah cabang dan usaha maksimal mendirikan cabang-cabang baru di seluruh provinsi di Indonesia. ${ }^{39}$

Berdasarkan pembagian periodisasi perkembangan Wahdah Islamiyah tersebut, tampak bahwa gerakan Wahdah Islamiyah mengalami proses moderasi dan persuasi tanpa kehilangan identitas sebagai gerakan puritanisme Islam. Pada tataran praksis, Wahdah Islamiyah bertranformasi menjadi gerakan yang lebih kontekstual dalam beradaptasi dengan kondisi dan kultur masyarakat. Sebagai gerakan puritanisme Islam, Wahdah Islamiyah tetap tidak meninggalkan agenda besarnya, yaitu pemurnian Tauhid

\footnotetext{
${ }^{38}$ Syarifuddin Jurdi, Wahdah Islamiyah ... h 160.

${ }^{39}$ Syarifuddin Jurdi, Wahdah Islamiyah... h 161-163.
} 
dan menghidupkan Sunnah, namun frame ukhuwah menjadi bingkai yang mengkontekstualisasi gerakan puritanisme Wahdah Islamiyah menjadi lebih persuasif dan moderat. Hal ini merupakan hasil dari sebuah proses panjang perjalanan Wahdah Islamiyah yang disebut oleh Syarifuddin Jurdi sebagai transformasi dari militan ke moderat-akomodatf.

Pemurnian Tauhid sebagai aksentuasi gerakan purifikasi Wahdah Islamiyah menjadi spirit dan orientasi gerak dalam modus gerakan dakwah dan tarbiyah. Sebagaimana yang diungkapkan oleh Rahmat Abdul Rahman, gerakan dakwah Wahdah Islamiyah adalah gerakan purifikasi atau pemurnian dan penyucian sifat tauhid dan akidah umat Islam dari segala kemusyrikan, berbentuk seruan kepada segenap lapisan masyarakat agar menjalankan kalimat syahadat yang telah mereka ikrarkan secara konsisten. Kalimat syahadat dan keislaman bukan sebatas identitas, namun dilalui sebagai jalan untuk sampai kepada Allah swt. Konsekuensi keislaman seseorang berupa pengamalan terhadap syariat agama, diserukan oleh ulama dan dai Wahdah Islamiyah dengan cara yang bijak, yaitu penyampaian dalil-dalil agama secara dalam dan memberikan solusi terhadap permasalahan yang terjadi di tengah umat Islam, serta menghindari perbuatan menghujat dan memojokkan sesama aktivis dakwah atau elemen umat yang berjuang buat kemajuan kaum muslimin, kecuali apabila terjadi penyimpangan nyata terhadap prinsip agama, maka akan dijelaskan sisi penyimpangannya tanpa menyebut pelakunya secara langsung. Pemurnian tauhid dan akidah Islam menjadi seruan prioritas dalam berdakwah, merupakan ruh yang selalu ditiupkan ke dalam jiwa setiap kader dan aktivis Wahdah Islamiyah. Berpedoman kepada Rasulullah saw. yang memulai gerakan dakwah dengan penyadaran terhadap Kemahaesaan Allah swt. untuk disembah, segenap permasalahan pada masa Jahiliyah dihubungkan dengan kerusakan visi Ketuhanan mereka yang berwujud pada kemusyrikan, sehingga perbaikan sistem bermasyarakat dimulai dari titik sentral tauhid dan akidah. ${ }^{40}$

Gerakan purifikasi akidah yang dikembangkan oleh Wahdah Islamiyah berlaku pada perbaikan mental, perilaku dan sistem beragama secara menyeluruh. Ajaran Islam yang telah sempurna tidak mungkin disikapi dengan pemurnian tauhid saja terlebih dahulu dan meninggalkan syariat lain sebagaimana periodesasi pada zaman Rasulullah saw., namun gerakan purifikasi akidah ini dilakukan secara sinergis dan integral dalam pelaksanaan sistem Islam di segala bidang dan lini kehidupan. ${ }^{41}$

Wahdah Islamiyah telah melembagakan gerakan purifikasi akidah ini dalam sistem pembinaan secara integral pada lini kehidupan yang dikelolanya. Sistem dakwah, pendidikan, sosial, ekonomi dan lingkungan hidup, telah menjadi satu kesatuan dalam gerakan yang terorganisir menuju peradaban yang tinggi seperti yang pernah dibuktikan oleh kaum muslimin pada zaman keemasannya, yaitu abad-abad awal hijriyah. Visi 2015 Wahdah Islamiyah untuk eksis di seluruh kabupaten sepulau Sulawesi dan ibukota

\footnotetext{
${ }^{40}$ Rahmat Abd. Rahman,"Wahdah Islamiyah.... “

${ }^{41}$ Rahmat Abd. Rahman,"Wahdah Islamiyah.... “
} 
propinsi di seluruh Indonesia, dimaknai sebagai media buat mengukuhkan gerakan purifikasi akidah ini, organisasi bagi aktivis Wahdah Islamiyah adalah sarana buat menyebarkan sistem kebaikan yang berdasarkan atas sifat tauhid dan kemurnian akidah Islam. $^{42}$

Wahdah Islamiyah termasuk gerakan Islam yang memposisikan Islam sebagai agama yang harus ditegakkan secara kaffah (total). Gerakan Wahdah Islamiyah merupakan manifestasi kecenderungan merespons nilai-nilai modernitas sekuler dank arena itu umat Islam harus berpegang teguh pada nilai-nilai dasar Islam(ushulliyah alIslamiyah). Dalam artian ini gerakan Wahdah Islamiyah merupakan gerakan fundamentalisme Islam, namun berbeda dengan fundamentalisme dalam kacamata Barat yang identik dengan radikalisme. Corak fundamentalisme Wahdah islamiyah dalam konstruksi awal ideologi Wahdah Islamiyah bagian dari upaya gerakan ini untuk melakukan pemurnian Islam dari pengaruh-pengaruh yang bukan Islam, bukan dalam pengertian fundamentalisme Barat yang cenderung negatif. ${ }^{43}$

Aspek pemurnian yang dilakukan oleh Wahdah Islamiyah adalah pada aspek fundamen Islam, yang berpulang pada komitmen memurnikan Tauhid dan menghidupkan Sunnah. Dalam hal menghidupkan Sunnah, Wahdah Islamiyah akan berbenturan dengan praktek tradisi keislaman masyarakat yang secara umum masih banyak mempraktekkan tradisi keislaman yang dalam kacamata Wahdah adalah bid'ah. Menyikapi hal tersebut, sebagaimana dituturkan oleh Ikhwan Abdul Jalil dalam buku Syarifuddin Jurdi, Wahdah Islamiyah merupakan gerakan Islam yang menjunjung tinggi budaya masyarakat, yang tidak sesuai dengan nilai-nilai otentik Islam akan dilakukan proses "Islamisasi" agar budaya tersebut menjadi perekat budaya masyarakat. ${ }^{44}:$ 'Islamisasi" inilah yang menjadi kerja strategis Wahdah Islamiyah dalam menghadapi tradisi dan budaya masyarakat yang menurut mereka bertentangan dengan nilai otentik Islam.

Pendekatan persuasif dan dialog senantiasa dikedepankan dalam menghadapi kenyataan praktek keagamaan masyarakat yang tidak sesuai dengan pandangan Islam otentik ala Wahdah Islamiyah. Tugas Wahdah Islamiyah adalah menyampakan dengan cara yang baik dan mengajak dialog tentang hal yang dianggap menyimpang tersebut. Namun, jika setelah diadakan dialog masyarakat yang bersangkutan masih tetap pada pendiriannya, maka sikap Wahdah adalah "berlepas diri”, karena hak keberagamaan adalah hak prerogatif seseorang. ${ }^{45}$ Sikap ini menunjukkan bahwa gerakan Wahdah Islamiyah meskipun sejatinya adalah gerakan puritan Islam, namun tidak bersikap frontal dan radikal sebagaimana kelompok puritanisme Islam lainnya. Wahdah Islamiyah memilih jalan moderat dalam mewujudkan misinya dengan senantiasa mengedepankan cara persuasi dan dialog.

\footnotetext{
${ }^{42}$ Rahmat Abd. Rahman,”Wahdah Islamiyah.... “

${ }^{43}$ Syarifuddin Jurdi, Wahdah Islamiyah... h 165.

${ }^{44}$ Syarifuddin Jurdi, Wahdah Islamiyah ... h 162.

${ }^{45}$ Wawancara dengan Ustaz Syaibani Sekjen DPP Wahdah Islamiyah tanggal 10 Januari 2018 di Makassar
} 
Wahdah Islamiyah dalam banyak statemennya menentang kekerasan atas nama monopoli kebenaran yang mengabaikan pluralitas. Yang patut dikerjakan adalah meningkatkan amalan sosial nyata yang dapat membebaskan umat Islam dari belenggu kebodohan dan keterbelakangan terutama dalam hal pemahaman keagamaan. Wahdah menyadari sepenuhnya, bahwa Islam adalah agama yang memberikan kebebasan kepada para pemeluknya untuk memahami dari berbagai sisi. Tingkah laku umat Islam bagi Wahdah haruslah bersandar pada makna-makna teks yang telah ditafsir, Islam bagi Wahdah Islamiyah tidak mengajarkan hal-hal buruk dalam menyebarkan ajarannya. Tidak satu pun cara kekerasan dilakukan oleh Nabi dalam mempengaruhi umat agar mau menerima Islam sebagai jalan hidupnya. ${ }^{46}$

Gerakan dakwah dan tarbiyah menjadi model strategis bagi Wahdah Islamiyah dalam menjalankan misinya sebagai organisasi Islam yang puritan. Dakwah yang dilakukan tdak hanya bersifat formal namun juga fokus pada dakwah yangbersifat bil hal. Wahdah dalam keseluruhan tafsirnya atas teks serta dalam dakwahnya tidak menonjolkan semangat kebencian dan permusuhan terhadap kelompok Islam lain diluar dirinya. Bagi Wahdah, persatuan dan kebersamaan harus terus digalakkan oleh kelompok-kelompok Islam dalam rangka membangun masyarakat. Dengan kata lain, setiap organisasi keagamaan berlomba-lomba dalam kebaikan, bukan mengedepankan sikap saling curiga dan kebencian.Memupuk Ukhuwah Islamiyah, tampaknya benarbenar teraktual secara nyata sebagai frame gerakan Wahdah Islamiyah yang mebuatnya menjadi lebih termoderasi.

Wahdah Islamiyah adalah organisasi yang bebas dan fleksibel dalam pemahaman keagamaan, sesuai dengan salafus salih. Wahdah Islamiyah merupakan gerakan Islam yang bersifat sosial keagamaan dan menghormati kultur masyarakat, anti disintegrasi, serta menentang cara yang tidak Islami dalam memperjuangkan Islam. Wahdah Islmaiyah memberikan penafsiran yang humanis terhadap makna dktrin ajaran Islam dengan mengembangkan konsep dakwah yang bersifat gradual, artinya tidak bersifat radikal. ${ }^{47}$

Tarbiyah menjadi model eksistensi gerakan Wahdah Islamiyah sejak berdirinya di tahun 1988.Sitem tarbiyah ini diinspirasi oeh system tarbiyah yang dikembangkan oleh kelompok Ikhwanul Muslimin. Sistem tarbiyah menjadi dasar bagi konstruksi lembaga dalam mempersiapkan diri untuk berpartisipasi dalam kehidupan sosio-politik bangsa di masa depan. Melalui system tarbiyah ini, Wahdah Islamiyah memiliki dua target atau cita-cita ke depan. Pertama, target yang bersifat normative yaitu suatu penyiapan terbentuknya manusia saleh, dapat bertindak sesuai dengan nilai-nilai Islam yang otentik serta terintegrasinya segala ucapan dan perbuatan, dan orientasi gerakan pada diri setiap kader. Kedua, target sosial-politik, yaitu upaya untuk menciptakan

\footnotetext{
${ }^{46}$ Syarifuddin Jurdi, Islam dan Politik Lokal: Studi Kritis atas Nalar Politik Wahdah Islamiyah,(Yogyakarta:Pustaka Cendekia Press,2006), h. 89.

${ }^{47}$ Sirajuddin Ismail, :’Wahdah Islamiyah di Kota Makassar" ... h. 130.
} 
kondisi atau lingkungan yang kondusif bagi manusia untuk hidup secara lurus, penuh dengan kedamaian, dan kasih-sayang kepada sesama manusia. ${ }^{48}$

Sebagai sebuah organisasi dakwah dan tarbiyah, Wahdah Islamiyah cukup ketat dalam rekruitmen keanggotaan. Pada saat ini terdapat tidak kurang dari ratusan kelompok tarbiyah yang terus melakukan pembinaan secara intensif yang dikelompokan menjadi 4 tingkat. Empat kelompok dimaksud adalah tingkat 1 pengenalan (takrifiyah), tingkat 2 pemula (tanfidiyah), tingkat 3 (takwidiyah) dantingkat 4 (tanfiz). Kelompok tarbiyah ini terkait dengan status mereka sebagai anggota Wahdah Islamiyah di mana setiap angggota yang aktif wajib mengikuti tarbiyah dan membayar donatur setiap bulan, sedangkan yang tidak pernah ikut akan dinonaktifkan. Polahirarki kekaderan ini menunjukkan betapa Wahdah Islamiyah cukup sistemik dalam hal memersiapkan kader dan anggotanya yang nantinya akan dipersiapkan sebagai agenagen dakwah mereka. Pola yang dilakukan oleh Wahdah Islamiyah ini, meskipun bukan sesuatu yang baru, karena sudah dilakukan juga oleh kelompok tarbiyah lainnya, seperti Ikhwanul Muslimin dan Hizbut Tahrir, namun tetap menunjukkan langkah maju dan sistemik dari Wahdah Islamiyah sebagai gerakan dakwah Islam yang modern.

Akhirnya, memahami gerakan Wahdah Islamiyah harus memetakan dan menganalisis secara cermat segala aspek agar tdak terjebak pada generalisasi dan simplifikasi dengan menyebutkan Wahdah Islamiyah sebagai gerakan Islam puritan yang radikal. Bahwa Wahdah Islamiyah adalah gerakan Islam puritan tetap harus diakui, namun membaca puritanisme gerakan Wahdah harus mempertimbangkan model dan pilihan sikap gerakannya yang bersifat washathiyah. Wahdah Islamiyah merupakan sebuah model "unik" dari gerrakan puritanisme Islam yang dalam tataran praksis memilih jalanmoderat dan persuasi sebagai jalan mereka untuk mewujudkan misi besar mereka. Dengan demikian, kita akan memosisikan Wahdah Islamiyah sebagai sebuah bentuk baru dari sebuah gerakan puritanisme Islamdi Indonesia, khususnya di Kota Makassar.

\section{PENUTUP}

Wahdah Islamiyah pada mulanya merupakan suatu gerakan Islam lokal yang menisbahkan dirinya kepada penyadaran, pencerahan, moral/akhlak dan pendidikan kini telah meluas ke berbagai wilayah di tanah air. Wahdah Islamiyah telah memiliki embrio yang kuat dan mengakar dengan Fathul Mu'in. Nama ini kemudian dipakai sebagai upaya untuk merekrut dan memelihara spirit keagamaan yang telah diwariskan oleh Fathul Mu'in Dg. Magading, seorang tokoh Muhammadiyah di Makassar pada dekade 1980-an; yang kemudian menginisiasi beberapa tokoh pendiri Wahdah Islamiyah untuk mendirikan Yayasan Fathul Mu'in (YFM).

Wahdah Islamiyah, adalah gerakan dakwah purifikasi atau pemurnian dan penyucian sifat Tauhid dan akidah umat Islam dari segala kemusyrikan. Gerakan

\footnotetext{
${ }^{48}$ Syarifuddin Jurdi, Wahdah Islamiyah... h 167.
} 
tersebut berbentuk seruan kepada segenap lapisan masyarakat agar menjalankan kalimat syahadat yang telah mereka ikrarkan secara konsisten Wahdah Islamiyah menjadikan akidah Ahlussunnah wal Jamaah sebagai manhaj dan dasar bagi pandangan dan gerakan purifikasinya. Ahlussunnah wal Jamaah yang dimaksud dalam hal ini adalah pemahaman dan pengertian agama seperti yang dilakukan oleh Rasulullah saw dan ulama salafus saleh yang terdiri dari sahabat, tabi'in dan tabi'it tabi'in. . Pandangan ini ditegaskan sebagaimana dalam poin pertama misi organisasi Wahdah Islamiyah, yaitu sebagai lembaga dakwah yang mengembangkan syiar Islam dan menyebarkan pemahaman Islam yang sesuai dengan Alquran dan Sunnah berdasarkan pemahaman para Salafussalih.

Meski Wahdah Islamiyah mengakui bahwa mereka adalah organisasi yang mengusung misi purifikasi Islam, bukan berarti Wahdah Islamiyah dapat dikategorikan sebagai kelompok takfirisme. Wahdah Islamiyah adalah organisasi dan gerakan Islam yang memilih jalan wasathiyah (tengah/moderat) sebagai frame gerakannya. Wahdah Islamiyah bertransformasi menjadi gerakan yang lebih kontekstual dalam beradaptasi dengan kondisi dan kultur masyarakat. Sebagai gerakan puritanisme Islam, Wahdah Islamiyah tetap tidak meninggalkan agenda besarnya, yaitu pemurnian Tauhid dan menghidupkan Sunnah, namun frame ukhuwah menjadi bingkai yang mengkontekstualisasi gerakan puritanisme Wahdah Islamiyah menjadi lebih persuasif dan moderat.

Gerakan dakwah dan tarbiyah menjadi model strategis bagi Wahdah Islamiyah dalam menjalankan misinya sebagai organisasi Islam yang puritan. Dakwah yang dilakukan tidak hanya bersifat formal namun juga fokus pada dakwah yang bersifat bil hal. Wahdah Islamiyah senantiasa mengedepankan cara-cara persuasif dan dialogis dalam mengembangkan metode dakwahnya di tengah masyarakat. Hal ini membuat Wahdah Islamiyah menjadi lebih bisa diterima di berbagai lapisan masyarakat meski mengusung visi puritanisme Islam. Meskipun cukup banyak benturan serta hambatan yang dihadapi Wahdah Islamiyah, namun tidak membuat kelompok ini lemah, bahkan mereka semakin eksis.

\section{DAFTAR PUSTAKA}

Abdullah, Amin. Dinamika Islam Kultural: Pemetaan Atas Wacana Keislaman

Kontemporer Bandung: Mizan, 2000

Azra, Azyumardi. Reposisi Hubungan Agama dan Negara, Jakarta: Penerbit Buku Kompas, 2002.

Bellah, Robert N. Beyond Belief, Essay on Religion in a Post-Tradisional Word. New York: Harper and Row, 1976.

Boisard, A. Marcer, Humanism in Islam, Terj. Humanisme dalam Islam, Jakarta: Bulan Bintang, 1986.

El Fadl, Khalid About, Selamatkan Islam dari Muslim Puritan, Terj. Helmi Musthofa Jakarta: Serambi, 2006. 
---------, “The Human Righs Commitmen in Modern Islam” dalam Joseph Runzo dan Nancy M. Martin (ed) Human Righs and Responsibilities in the Word Religion, Oxford: Oneworld, 2003.

, Cita dan Fakta Toleransi Islam, Puritanisme Versus Pluralisme. Terj. Eka Prasetya. Bandung: Mizan. 2003.

Esposito, John L. Thes Oxford Encyclopedia of The Moderen Islamic World. Diterjemahkan oleh Eva Y.N. Femy S. dkk dengan judul Ensiklopedia Dunia Islam Moderen. Jilid.2; Bandung: Mizan, 2002. The Islamic Threat: Myth or Reality Oxford: Oxford University Press. 1992.

Fealy, Greg dan Anthony Bubalo.. Jejak Kafilah: Pengaruh Radikalisme di Indonesia. Bandung: Mizan. 2007.

Gellner, Ernest. Fundamentalism as a Comparative System: Soviet Marxism and Islamic Fundamentalism Compared. Chicago: University of Chicagos. Press. 1995.

Hadiati, "Komunikasi Dakwah Wahdah Islamiyah di Sulawesi Selatan”, Jurnal Komunikasi Islam Volume 06 Nomor 01 Juni 2016.

Imarah, Muhammad. Fundamentalisme dalam Perspektif Barat dan Islam. Yokyakarta: Gema Insani Press. 1999.

Jahroni, Jamhari Jajang. Gerakan Salafi Radikal di Indonesia. Cet. I; Jakarta: PT. Raja Grafindo Persada, 2004.

Jurdi, Syarifuddin, Sejarah Wahdah Islamiyah: Sebuah Geliat Ormas Islam di Era Transisi, Yokyakarta: Kreasi Wacana, 2007.

---------, Wahdah Islamiyah dan Gerakan Transnasional: Hegemoni, Kompromi, dan Kontestasi Islam Indonesia, Yokyakarta: Laboratorium Sosiologi UIN Sunan Kalijaga, 2009.

--------, Islam dan Politik Lokal: Studi Kritis atas Nalar Politik Wahdah Islamiyah, Yokyakarta: Pustaka Cendekia Press, 2006.

Lee, Robert D. Mencari Islam Autentik: Dari Nalar Puitis Iqbal Hingga Nalar Kritis Arkoun, Terj. Ahmad Baiquni Bandung: Mizan. 2000.

Madjid, Nurcholsh. Kaki Langit Peradaban Islam. Jakarta: Paramadina. 1997. Islam, Doktrin, dan Peradaban. Jakarta: Paramadina, 1992.

Rahmat, Imdadun., "Islam Pribumi: Mencari Wajah islam Indonesia", dalam Jurnal Tashwirul Afkar Edisi Nomor 14 tahun 2003.

al-Maragi, Ahmad Mustafa. Tafsir al-Maragi, Jili. III; Beirut: Dar-al-Fikr, [t.th]. Mubarak, M. Zaki, Genealogi Islam Radikal di Indonesia: Gerakan, Pemikiran dan Prospek Demokrasi, Jakarta: Pustaka LP3ES Indonesia, 2007.

Muchtar, A. Latif, Gerakan Kembali ke Islam, Bandung : Rosda Karya, 1998. Ma'luf, Louis. Al-Munjid Fi-al-Lughah. Beirut: Dar-al-Masyriq, 1977.

Muhammad, Syarifuddin. Manhaj Teologi Radikal. Bandung; Pustaka Setia, 2009.

Mujani, Saiful. "Di Balik Polemik anti-Pembaruan Islam: Memahami Gejala 
Fundamentalisme Islam", dalam Islamika, Nomor I 1993,

Mujiburrahman, Mengindonesiakan Islam: Representasi dan Ideologi. Yokyakarta:

Pustaka Pelajar. 2008.

Nata, H. Abuddin. Peta Keragaman Pemikiran Islam di Indonesia. Cet. II; Jakarta: PT. Raja Grafindo Persada, 2001.

Noer, Delier, Gerakan Modern Islam Indonesia 1900-1945, Jakarta: LP3ES, 1982.

Peacock, James L. Muslim Puritans: Reformis Psycology in South East Asian Islam. Barkeley: University of California Pres. 1978.

Qardhawi, Yusuf. Al-Shahwah al-Alislamiyah bain al-Juhud wa al-Tatharuf,

Diterjemahkan oleh Hawin Murthado dengan judul Islam Radikal; Analisis terhadap Radikalisme dalam Berislam. Cet. I; Solo: Intermedia, 2004.

Rahman, Rahmat Abd..”Wahdah Islamiyah Gerakan Purifikasi Akidah", www.wahdah.or.id. Diakses pada tanggal 7 Juni 2017.

Rahman, Fazlur. Islam. Cet.II; Chicago \& London: University of Chicago Press, 1979.

Rahmat, Jalaluddin. Fundamentalisme Islam: Mitos dan Realitas, Dalam Prisma, No. Ekstra, 1984.

Setiawan, Rahmat. Rasionalisme dan Fideisme Teologi, Bandung: Pustaka Hidayah. 2004.

Sjadzali, Munawir. Islam dan Tata Negara: Ajaran, Sejarah dan Pemikiran, Jakarta: UI-Press, 1993.

Situmorang, Jubair. Fundamentalisme Dalam Islam dalam Adnan Mahmud dkk (ed) Pemikiran Islam Kontemporer Di Indonesia. Cet. I; Yogyakarta: Pustaka Pelajar, 2005.

Tajuddin, Muhamamd Saleh. "Pemikiran dan Gerakan Politik Organisasi Wahdah Islamiyah di Sulawesi Selatan" dalam Jurnal al-Fikr, Volume 17No1 tahun 2013.

Wahid, Abdurrahman (ed), Ilusi Negara Islam: Ekspansi Gerakan Islam

Transnasional di Indonesia, Jakarta: Gerakan Bhineka Tunggal Ika-the Wahid Institute-the Maarif Institute. 2009.

Waskito, AM. Bersikap Adil Kepada Wahabi: Bantahan Kritis dan Fundamental Terhadap Buku Propaganda Karya Syaikh Idahram, Jakarta: Pustaka alKautsar, 2012.

Zada, Khamami. Islam Radikal Pergulatan Ormas-Ormas Islam Garis Keras di Indonesia. Cet. I; Jakarta: Teraju, 2002. 